\title{
Motivation, Productivity Growth, and Business Financial Performance - A Scoping Review Approach to Linkages and Impact
}

\author{
Article by Gillow Christopher \\ Gillow Christopher, Texila American University, Nigeria \\ E-mail: christophergillow@yahoo.com
}

\begin{abstract}
The objectives of this research were to understand the nature of the relationship between three concepts namely, motivation, productivity, and financial performance. To answer the research questions posed, the researcher followed a scoping literature review approach to arrive at only 8 studies which are relevant to this present research. The results from this present research are that (1) the nature of the relationship between motivation, productivity and financial performance is positive. (2), the extent of the impact may not be that great as one study shows that without the inclusion of capital intensity, motivation has no relationship with productivity and financial performance. This research contributed to existing body of knowledge by identifying the nature of the relationship between motivation, productivity and financial performance which has received little attention from researchers.
\end{abstract}

\section{Introduction}

There is plethora of literature which describe individually, the concept of motivation, productivity growth, and business financial performance. Some papers have sort to address motivation in workplace. Others concentrate on factors impacting on employee productivity and many papers on factors influencing business financial performance. While many papers address these concepts individually, we could not find many which look into the linkage between these three variables such as, Motivation, Productivity and firm Financial performance. Thus, there is a gap in literature which needs to be addressed. We therefore intend to fill this gap by putting the pieces together from various sources of research using scoping review approach.

\section{Research objectives}

Given the limited knowledge in the area of the linkage between motivation, productivity and firm financial performance, the focus of the paper rests on the following objectives

- To understand the nature of the relationship between motivation, productivity and firm financial performance

- To assess the extent to which the variables impact on one another

\section{Research questions}

Following the objectives set for this research, the questions to focus on are as follow:

1. What is the nature of the relationship between motivation, productivity growth, and financial performance?

2. To what extent does motivation, impact on productivity growth and business financial performance?

\section{Research rationale}

This research is produced in response of a capstone research required to address three individual modules which are

- Management Principle and Organizational Behavior, (represented by Motivation)

- Business Accounting and Financial Management (represented by Financial Performance)

- Production and Operations management (represented by productivity growth) 
DOI: 10.21522/TIJMG.2015.SE.19.01.Art018

ISSN: $2520-310 \mathrm{X}$

This research will therefore be useful to operations managers, HR Managers accounting and finance departments as well as strategic managers in decision making

\section{Research structure}

In order to properly address the objective of this research, the following is followed. Section 2 introduce the concepts of motivation, productivity and financial performance, as well as their theoretical background. Section 3 describes the methodology used. Section 4 identifies and synthesizes the relevant theoretical literature on how the concepts link to one another. Section 5 tries to make sense of the pieces of information gotten by presenting them in charts and tables. Section 6 collates, summaries and reports findings. Lastly, section 7 identifies the limitations of the study and recommends areas for further study

\section{Conceptual framework}

This section is dedicated to the explanation of the individual concepts (Motivation, Productivity and Financial performance) which are of interest to this paper

\section{Motivation}

Motivation is probably one of the most renowned topics in the study of organizational behavior. Why people do what they do and do it very well is termed as motivation. According to Shields (2007), motivation is the source of job behavior or strength, and it denotes the power of an individual's inclination to actualize a given task. The workplace today's requires motivation. The necessary drives given to employees that assist firms to attain major competitive edges, improved efficiency and of course overall improvement in profitability. Motivation plays a fundamental role in all entity. It can be adopted as an instrument that reveals the state at which workers and the entire organization is performing. Most manager in every organization face workplace challenge such as lack of employee morale or dedication, late delivery declining levels of productivity (Surridge \& Gillepsi, 2015). Others are poor quality outputs from the workers and in extreme cases high labor turnover.

In trying to come up with best methods of motivation people, many theories have emerged. Some of which can be categorized as content theories and others process theories. Other papers also differentiate between intrinsic and extrinsic motivation. Some of the notable content theories of motivation are Taylors theory of money as a sole motivator of people to work, Maslow's Hierarchy of needs which argue that people can only be motivated by things they do not already have, and Herzberg two-factor theory which argue that money does not motivate people to work, it only removes dissatisfaction at work (Surridge \& Gillepsi, 2015). Herzberg argues that what motivates people are things like responsibility, empowerment, promotion and the need for self-actualization. On the other hand, process theories of motivation are those which talk about the processes involved before people are actually motivated. Vrooms Expectancy theory is one of the notable process theories highlighted in Bobby (2015). Vroom argues that motivation can only occur if three conditions are met. (1) the employee has an expectation from the employer. (2) He believes that achieving the outcome or targets will lead to his expectation, and (3) believing that he can achieve the desired outcome or target. Other authors explain that motivation can be achieved intrinsically (doing something because of the satisfaction derived from the doing it) and Extrinsically (doing something because of an associated reward). These authors opine that the best methods of motivation should address it both intrinsically and extrinsically (Surridge \& Gillepsi, 2015). Nonetheless, haven introduced the concept of motivation, it is necessary to highlight the role of motivation in organizations

\section{Productivity}

According to Harari (2015), productivity growth can simply be defined as the increase in output per employee. Producing more with available scarce resources has been the struggle of managers since the beginning of industrialization. Increasing output without a corresponding increase in inputs reduces cost of production which in turn increases profits, described in Kafouros (2005) as productivity growth. In addition, 
productivity can be said to represent how efficiently inputs (labour, capital, materials) are utilized in the production process (Kafouros, 2005).

Harari (2015) has proven that productivity growth is essential for businesses growth, Thus, the benefits from productivity growth has caused employers, corporations and government bodies to take as several measures as necessary to ensuring that productivity is constantly on the increase. There are several ways of achieving productivity growth commonly used by operations mangers. They include investment in equipment and technology, increasing the number of hours worked, training, changing the way work is done, and finally through motivation of employees. In this research, the link we are looking for is that with motivation

\section{Business financial performance}

Business Performance can be measured both financially and non-financially. Financial performance takes an accounting approach to business success like profitability, liquidity, etc. While non-financial performance takes the form of managerial assessment of factors such as customer satisfaction, employee satisfaction, innovation ability, etc. Thus, and accounting view of business success takes a more objective dimension. The business financial (Accounting) performance and non-financial indicators frequently used are illustrated on table 1 below, extracted from the work of Santos \& Brito (2012)

Table 1. Performance dimentions and indicators

\begin{tabular}{|c|c|}
\hline Dimensions & Selected Indicators \\
\hline Profitability & $\begin{array}{l}\text { Return on Assets, EBTIDA margin, Return on investment, Net income/Revenues, } \\
\text { Return on equity, Economic value added }\end{array}$ \\
\hline Market Value & $\begin{array}{l}\text { Earnings per share, Stock price improvement, Dividend yield, Stock price volatility, } \\
\text { Market value added (market value / equity), Tobin's q (market value / replacement } \\
\text { value of assets) }\end{array}$ \\
\hline Growth & $\begin{array}{l}\text { Market-share growth, Asset growth, Net revenue growth, Net income growth, } \\
\text { Number of employees growth }\end{array}$ \\
\hline Employee Satisfaction & $\begin{array}{l}\text { Turn-over, Investments in employees development and training, Wages and rewards } \\
\text { policies, Career plans, Organizational climate, General employees' satisfaction }\end{array}$ \\
\hline Customer Satisfaction & $\begin{array}{l}\text { Mix of products and services, Number of complaints, Repurchase rate, New } \\
\text { customer retention, General customers' satisfaction, Number of new } \\
\text { products/services launched }\end{array}$ \\
\hline $\begin{array}{l}\text { Environmental } \\
\text { Performance }\end{array}$ & $\begin{array}{l}\text { Number of projects to improve / recover the environment, Level of pollutants } \\
\text { emission, Use of recyclable materials, Recycling level and reuse of residuals, } \\
\text { Number of environmental lawsuits }\end{array}$ \\
\hline Social Performance & $\begin{array}{l}\text { Employment of minorities, Number of social and cultural projects, Number of } \\
\text { lawsuits filed by employees, customers and regulatory agencies }\end{array}$ \\
\hline
\end{tabular}

Table Source: (Santos \& Brito, 2012).

The work of Al-Jarrah, \& Tarhini (2015) classifies the three first categories such as profitability, market value and growth as financial performance indicators, while the rest as non-financial performance indicators. Consistent with this, IGIGlobal (2018) also enumerate indicators such as revenue, return on equity, return on assets, profit margin, sales growth, capital adequacy, liquidity ratio, and stock prices as commonly indicators to evaluate the financial performance of organisations. Thus, interest on this present research are on papers which seek to address the link between these financial indicators with other variables of interest such as motivation and productivity. 
DOI: 10.21522/TIJMG.2015.SE.19.01.Art018

ISSN: $2520-310 \mathrm{X}$

\section{Theoretical enquiry into motivation, productivity growth and financial performance}

There is a plethora of literature on the close relationship between motivation and employee performance (in terms of productivity). However, only a few papers have found a connection between motivation and organizational financial performance. The link between productivity itself with financial performance has also been explored by just a very few papers. In this section, we examine these theoretical backgrounds.

It is widely known among organizational behavior researchers that motivation enhances employee performance at work thus, increasing productivity. It is believed that when employees are happy with their job, they will do extra which in turn increases productivity at work. Motivation is about those things that push you to do what you do, and do it very well (Surridge \& Gillepsi, 2015). If that is the case, then performance has something to with motivation. Many academic papers have proven the relationship between motivation and performance empirically. For instance, Afful-Broni (2012), and Said, Zaidee, Zahari, Ali, \& Salleh, (2015) provide strong argiment for such relationshop with empirical evidence. Mathematically, the relationship is represented as, Performance $=$ F (Ability X Motivation) + error term................ (1) Where, the error term are other factors which cannot be controlled by the individual which also influence performance. E.g. weather conditions, type of technology used by the organization, etc. Surridge \& Gillepsi (2015) further adds that motivated workforce will exhibit low absenteeism, low labour turnover and high level of productivity. Thus, a business that enjoys the benefit of a highly motivated workforce is also likely to have a productive workforce. As productivity increases, this will translate to low production cost. Low production cost could mean two things for a business. Firstly, the business will be able to sell their products at a competitive price thus, increasing revenue. Secondly, the business can maintain their price level and enjoy greater profits. Both of these performance indicators (sales growth and profit) are those grouped under financial performance by IGIGlobal (2018), and Al-Jarrah, \& Tarhini (2015) . Thus, one can appreciate the interconnected between motivation, productivity and financial performance. Nevertheless, while the link between motivation and productivity growth has been widely examined, as well as productivity growth and financial performance, little attention has been given to motivation and firm financial performance. Therefore, this present research seeks to explore the evidence available for the interconnectedness between motivation, productivity growth and business financial performance.

\section{Methodology}

The main objective of this research is to assess the interconnectedness between motivation, productivity growth and financial performance of businesses. Two research questions were specified in section 1 to address the objectives set. To address the research questions posed, the author used newly introduced scoping review approach. This meant that several online data bases such as EBSCO Host, Science Direct, and Business Source Complete were used to gather papers on the topic. The search text was 'Motivation, and Productivity, and Financial Performance'. Over 10,000 search results were found. The author narrowed it down by first eliminating papers which focused only on $1 / 3$ of the subjects of interest. That is, papers which do not have words such as productivity and financial performance or motivation and productivity, or at least, any $2 / 3$ from the search results. The author furthers goes through the abstracts of the retained papers to further select the most suitable papers for the topic. Thus, the author arrived at only 8 out of initially planned 10 suitable papers for the analysis. This approach to research is consisted with the idea of Arksey \& O'Malley (2005), described in (Dijkers, 2015). According to the authors, scoping review aims to map rapidly the key concepts underpinning a research area and the main sources and types of evidence available, and can be undertaken as stand-alone projects in their own right, especially where an area is complex or has not been reviewed comprehensively before.

Dijkers (2015) further differentiates scoping review from a systsematic review by stating that (1), a systematic review might typically focus on a well- defined question where appropriate study designs can be identified in advance, whilst a scoping study tends to address broader topics where many different study designs might be applicable. (2), the systematic review aims to provide answers to questions from a relatively narrow range of quality assessed studies, whilst a scoping study is less likely to seek to address very specific 
research questions nor, consequently, to assess the quality of included studies. The below figure shows the steps described by Arksey \& O'Malley (2005) for authors wishing to undertake scoping review to follow, which this present study has followed

\section{Steps for undertaking a scoping review as outlined in arksey \& o'malley (2005)}

1. Identify the research questions: what domain needs to be explored?

2. Find the relevant studies, through the usual means: electronic databases, reference lists (ancestor searching), websites of organizations, conference proceedings, etc.

3. Select the studies that are relevant to the question(s)

4. Chart the data, i.e. the information on and from the relevant studies

5. Collate, summarize and report the results

6. (Optional) consult stakeholders (clinicians, patients and families, policy makers, or whatever is the appropriate group) to get more references, provide insights on what the literature fails to highlight, etc.

Because of the time and money involved in step 6 which is optional, Dijkers (2015) opines that authors have generally skipped that step to stop at step 5. Thus, our research also stops at step 5. Nevertheless, scoping review method has been criticised for its lack of quality assessment of papers included in the review and its lack of methodolycial quality assessment of of studies used (Peterson, Pearce, Ferguson, \& Langford, 2017). Nonetheless, we found the scoping review approach suitable for the this resarch for the following reasons. Firstly, our interest is not with the quality of papers or methodological frameworks, but on the actual information and results reported. Secondly, our topic (relationship between motivation, productivity and financial performance) is a broad area which is also not a widely researched area thus, scoping review has been recommended by Dijkers (2015) for this type of research topic.

\section{Synthesis and analysis of relevant studies}

A Total of 8 relevant studies were found which are useful to this research. Information regarding these studies are presented in this section.

The first paper is Huselid (1995). This paper is relevant as it studies $3 / 3$ of the variables of interest. That is, it assesses the interconnetedness between motivation, productivity and financial performace. The author used OLS and Two-Stage Least Square regression analysis to the assess the impact of human resoruces practicies (e.g motivation) on variables such productivity, and the profitability of the businesses for a sample 3,452 US firms representing major industries. The paper finds that motivation increased productivity of employees as well as the financial performance of the business

The second selected paper is Hubbard (2014). This Paper is also significant to this present study. The three key words, motivation, productivity and profit appeared on the paper (3/3). The author documents survey results undertaking by PTD among South African workers. The survey sampled 1000 participants using questionnaire and secondary sources to get information on how levels of motivation affects productivity and the organisations profits and also reports similar findings to that in Huselid (1995).Specifically, Hubbard finds that organisations with engaded workforce had up to $6 \%$ higher net profit. Thus arguing that motivation has positive relationship to both productivity and financial performance of businesses.

The third selected paper is Richard \& Johnson, (2001). This paper also investigates $3 / 3$ of our interested araes. The authors surveyed 73 employees of banks in Califonia and Kenturkey. Secondary sources of data on financial measures was also obtained and Hierarchical regression analysis was used to test hypothesis devepoled around motivation, productivity and financial performance. In contrast with previous findinds, motivation was found not have any rlationship with productivity and financial performance. This result appears rather unique and substantially different from other studies. Although the paper reports that motivation only affected both productivity and return of equity (financial performance) when moderated by capital intensity. 
DOI: 10.21522/TIJMG.2015.SE.19.01.Art018

ISSN: $2520-310 \mathrm{X}$

This however makes sense as productivity of employees may also depend on the state of technology used which inturn may impact on frim costs.

The $4^{\text {th }}$ paper of interest is Ionescu (2017). This paper only encoporates $2 / 3$ of the variables of interest. It only investigates the relationship between productivity and business financial performance. However, the paper is still relevant to this study as our interest is to gather enough evidence about the relationship among the three different areas of study. Ionescu (2017) used theoretically based empirical research to review the work of Grifell-Tatjé and Knox Lovell (2015) on productivity accounting and financial performance and finds that productivity is a significant contributor of firms' financial performance.

The fifth paper selected is Terpstra \& Rozell (1993). This paper captures only $2 / 3$ of our topic areas. The authors focused only on HR motivation practices and business financial performance. The paper is also relevant as our inclusion criteria is minimum of $2 / 3$ of the topics of interest. Terpstra \& Rozell (1993) suyved 201 heads of HRM departments from 1000 organisations in U.S and further obtains secondary data for the financial performance indicators used. The data was subjected to hierarchical regression analysis and results show significant positive relationship between motivation and both annual profits and profits growth across all the industries in the sample.

The $6^{\text {th }}$ paper of interest is Heymann (2011). The paper meets 3/3 of the topic areas of interest.The author interviewed CEOs of different companies around the world, Norway, U.S, Canada and South Africa and documents findings on the relatiinship between motivation, productivity and financial performance. The paper also reports a positive relationship between motivation, productivity and business financial performance.

The $7^{\text {th }}$ paper is Schiemann, (1987). The author also investigates $3 / 3$ of our areas of interest. The work is a literature based research but no methodological approach is mentioned on the paper. Nevertheless, the paper also reports a positive relationship between motivation, productivity and business financial performance.

The $8^{\text {th }}$ paper of interest is Ravichandran \& Bano (2016). The authors used a meta-analyis approach to investigate $2 / 3$ of our research interest. Specifically, they investigated the relationship between motivation and productivity and also report a positive relationship. Although the paper mentioned firm perormance, it does not state whether this is financial and non-financial performance as such, this research cannot assume this is financial performance thus, we record only motivation and productivity which is $2 / 3$.

\section{Charts of data/information collected from selected relevant studies}

From the information gathered on the nature of the relationship between motivation, productivity and financial performance, the following charts below are constructed.

Table 2. Papers used and results obtained

\begin{tabular}{|l|l|l|l|l|l|}
\hline S/N & Paper & $\mathbf{M + P}$ 2/3 & $\mathbf{M + F P ~ 2 / 3}$ & $\mathbf{P + F P ~ 2 / 3}$ & $\mathbf{M + P + F P ~ 3 / 3 ~}$ \\
\hline $\mathbf{1}$ & Huselid (1995) & - & & - & Positive \\
\hline $\mathbf{2}$ & Hubbard (2014) & - & & - & Positive \\
\hline $\mathbf{3}$ & $\begin{array}{l}\text { Richard \& Johnson } \\
\text { (2001) }\end{array}$ & Positive & & - & $\begin{array}{l}\text { Positive upon } \\
\text { addition of } \\
\text { capital intensity }\end{array}$ \\
\hline $\mathbf{4}$ & Ionescu (2017). & - & - & - & - \\
\hline $\mathbf{5}$ & $\begin{array}{l}\text { Terpstra \& Rozell } \\
\text { (1993). }\end{array}$ & - & Positive & - & - \\
\hline $\mathbf{6}$ & Heymann (2011). & - & - & - & Positive \\
\hline $\mathbf{7}$ & Schiemann, (1987). & - & - & - & Positive \\
\hline $\mathbf{8}$ & $\begin{array}{l}\text { Ravichandran \& Bano } \\
\text { (2016). }\end{array}$ & - & Positive & - & - \\
\hline
\end{tabular}

$\mathbf{M}=$ motivation, $\mathbf{P}=$ productivity, $\mathbf{F P}=$ financial performance 


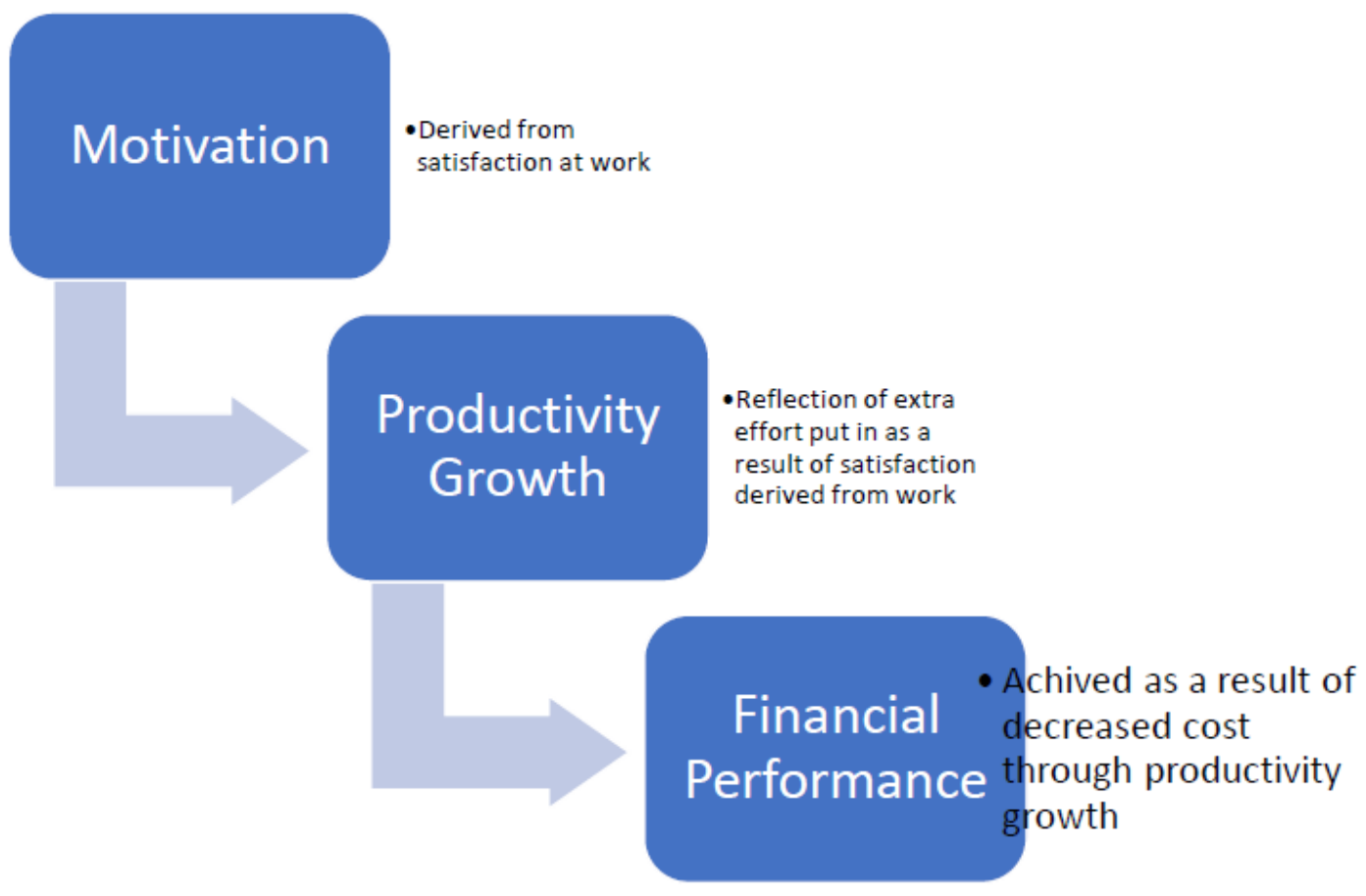

Figure 1. Illustration of the results

\section{Collation, summarizing and reporting of results}

The objectives of this research have been to understand the nature of the relationship between three concepts namely, motivation, productivity, and financial performance. From the objective, two research questions were posed which are,' What is the nature of the relationship between motivation, productivity growth and financial performance? and 'To what extent does motivation impact on productivity growth and financial performance? To answer the research questions posed, the researcher followed a scoping literature review approach to arrive at only 8 studies which are relevant to this present research.

The results from this present research are that (1) the nature of the relationship between motivation, productivity and financial performance is positive. This means that increased motivation will lead to increases productivity and increased business financial performance. For the second question (2), the extent of the impact of motivation on productivity growth and business financial performance may not be very great as one of the studies reviewed shows that without the inclusion of capital intensity, motivation has no relationship with productivity and financial performance. The implication of this findings that both strategic managers, HR managers operations mangers and accounting departments have to work together and integrate strategies for business success.

\section{Limitation of research and recommendations for future studies}

The limitations of this study are those associated with the scoping review approach. Firstly, its inability to carry out empirical investigation. Additionally, no quality assessments were conducted in order to eliminated papers found wanting. Thirdly, although it optional, no consultation of professionals in the field was done to determine definition of terms used in the work or type of papers and materials to be included. Thus, it is recommended for further studies to adopt a different approach, preferably an approach which would allow for empirical investigation in order to assess the topic. 
DOI: 10.21522/TIJMG.2015.SE.19.01.Art018

ISSN: $2520-310 \mathrm{X}$

\section{Reference}

[1]. Arksey, H., \& O'Malley, L. (2005). Scoping studies: towards a methodological framework. International Journal of Social Research Methodology, 8(1), 19-32.

[2]. Bobby, D. (2015). Introduction to Work and Organizational Behavior. Harlow: Pearson.

[3]. Chari, V., Christiano, L., \& Kehoe, P. J. (2008). Facts and Myths about the Financial Crisis of 2008. Kehoe: Federal Reserve Bank of Minneapolis Research Department.

[4]. Dijkers, M. (2015). What is a Scoping Review? Center on Knowledge Translation for Disability and Rehabilitation Research, 1(4).

[5]. Harari, D. (2015). Productivity in the UK. London: House of Commons Library.

[6]. Heymann, J. (2011). Investing at the Bottom of the Ladder: Companies that invest in their lowest-level employees are more productive and more profitable. Stanford Social Innovation Review.

[7]. HUBBARD, J. (2014). SA's employees' tuning out. Finweek.

[8]. HUSELID, M. A. (1995). THE IMPACT OF HUMAN RESOURCE MANAGEMENT PRACTICES ON TURNOVER, PRODUCTIVITY, AND CORPORATE FINANCIAL PERFORMANCE. Academy of Management Journal, 38(3), 635-672.

[9]. IGIGlobal. (2018). What is Firm Performance. Retrieved from IGI Global: https://www.igiglobal.com/dictionary/firm-performance/51090

[10]. Ionescu, L. (2017). PRODUCTIVITY ACCOUNTING AND BUSINESS FINANCIAL PERFORMANCE: A REVIEW OF CURRENT EVIDENCE. Economics, Management, and Financial Markets, 12(2), 67-73.

[11]. Kafouros, M. I. (2005). R\&D and productivity growth: Evidence from the UK. Economics of Innovation and New Technology, 14(6), 479-497. doi:10.1080/1043859042000269098

[12]. Kocabiyıkoglu, A., \& Popescu, I. (2007). Managerial Motivation Dynamics and Incentives. MANAGEMENT SCIENCE, 53(5), 834-848.

[13]. Masa'deh, R., (Tayeh, M., Al-Jarrah, I. M., \& Tarhini, A. (2015). Accounting vs. Market-based Measures of Firm Performance Related to Information Technology Investments. International Review of Social Sciences and Humanities, 9(1), 129-145.

[14]. Peterson, J., Pearce, P. F., Ferguson, L. A., \& Langford, C. A. (2017). Understanding scoping reviews: Definition, purpose, and process. Journal of the American Association of Nurse Practitioners, 29, 12-16.

[15]. Ravichandran, N., \& Bano, R. (2016). A Review of Antecedents, Correlatesand Consequences of HR Practices: A Conceptual Model of Organizational Development.

[16]. Richard, O. C., \& Johnson, N. B. (2001). Strategic human resource management effectiveness and firm performance. International Journal of Human Resource Management, 12(2), 299-310.

[17]. Santos, J. B., \& Brito, L. A. (2012). Toward a Subjective Measurement Model for Firm Performance. Journal of Brazilian Administration Review, 9(6), 95-117.

[18]. Schiemann, W. A. (1987). THE IMPACT OF CORPORATE COMPENSATION AND BENEFIT POLICY ON EMPLOYEE ATTITUDES AND BEHAVIOR AND CORPORATE PROFITABILITY. JOURNAL OF BUSINESS AND PSYCHOLOGY, 2(1).

[19]. Shields, J. (2007). Managing employee performance and reward. Cambridge University Press, Cambridge.

[20]. Surridge, M., \& Gillepsi, A. (2015). Cambridge A Level Business. London: Hodder Education.

[21]. TERPSTRA, D. E., \& ROZELL, E. J. (1993). THE RELATIONSHIP OF STAFFING PRACTICES TO ORGANIZATIONAL LEVEL MEASURES OF PERFORMANCE. PERSONNEL PSYCHOLOGY, 46. 